Int. J. Electrochem. Sci., 14 (2019) 5026 - 5041

International Journal of

ELECTROCHEMICAL

SCIENCE

www.electrochemsci.org

\title{
Use of Curcuma and Curcumin as a Green Corrosion Inhibitors for carbon Steel in Sulfuric Acid
}

\author{
E.A. Flores-Frias ${ }^{1}$, V. Barba ${ }^{2}$, M.A. Lucio-Garcia ${ }^{3}$, R. Lopez-Cecenes ${ }^{1}$, J. Porcayo-Calderon ${ }^{1}$, \\ J.G. Gonzalez-Rodriguez, ${ }^{1, *}$ \\ ${ }^{1}$ Universidad Autonoma del Estado de Morelos, CIICAp, Av. Universidad 1001-62209- \\ Cuernavaca,Mor., Mexico \\ ${ }^{2}$ Universidad Autonoma del Estado de Morelos, CIQ, Av. Universidad 1001-62209-Cuernavaca,Mor., \\ Mexico \\ ${ }^{3}$ Universidad Autonoma de Yucatan, Facultad de Quimica, C. 43 No. 613 X C. 90, Inalámbrica 97069, \\ Mérida, Yucatán, México. \\ *E-mail: ggonzalez@uaem.mx
}

doi: $10.20964 / 2019.06 .53$

Received: 1 March 2019 / Accepted: 4 April 2019 / Published: 10 May 2019

The use of Curcuma (Curcuma longa L.) extract as a green corrosion inhibitor for 1018 carbon steel in $0.5 \mathrm{M} \mathrm{H}_{2} \mathrm{SO}_{4}$ solution has been evaluated by using weight loss tests, potentiodynamic polarization curves and electrochemical impedance spectroscopy measurements. Results have shown that Curcuma longa $L$. decreased the weight loss by one and the corrosion current density values by two orders of magnitudes. Results of free energy suggest physical adsorption on to the steel surface obeying a Langmuir type of adsorption isotherm. Polarization studies give evidence that Curcuma longa L. extract behaves as a predominantly cathodic type of inhibitor, and its efficiency increases with increasing its concentration, reaching a maximum value of $90 \%$.

Keywords: Carbon steel, acid corrosion, green inhibitor.

\section{$\underline{\text { FULL TEXT }}$}

(C) 2019 The Authors. Published by ESG (www.electrochemsci.org). This article is an open access article distributed under the terms and conditions of the Creative Commons Attribution license (http://creativecommons.org/licenses/by/4.0/). 